\title{
5-Lipoxygenase Pathway, Dendritic Cells, and Adaptive Immunity
}

\author{
Harizi Hedi* and Gualde Norbert \\ CNRS, UMR 5540, University Bordeaux 2, 33076 Bordeaux Cedex, France
}

Received 30 October 2003; revised 10 February 2004; accepted 11 February 2004

\begin{abstract}
5-lipoxygenase (5-LO) pathway is the major source of potent proinflammatory leukotrienes (LTs) issued from the metabolism of arachidonic acid (AA), and best known for their roles in the pathogenesis of asthma. These lipid mediators are mainly released from myeloid cells and may act as physiological autocrine and paracrine signalling molecules, and play a central role in regulating the interaction between innate and adaptive immunity. The biological actions of LTs including their immunoregulatory and proinflammatory effects are mediated through extracellular specific G-protein-coupled receptors. Despite their role in inflammatory cells, such as neutrophils and macrophages, LTs may have important effects on dendritic cells (DC)-mediated adaptive immunity. Several lines of evidence show that DC not only are important source of LTs, but also become targets of their actions by producing other lipid mediators and proinflammatory molecules. This review focuses on advances in 5-LO pathway biology, the production of LTs from DC and their role on various cells of immune system and in adaptive immunity.
\end{abstract}

\section{INTRODUCTION}

Leukotrienes (LTs) are an important family of eicosanoid lipid mediators derived from the metabolism of arachidonic acid (AA) and associated with asthma and allergic reactions [1]. In contrast to prostaglandins (PGs), which are produced from AA by the action of cyclooxygenase (COX) enzymes, LTs are made predominately by inflammatory cells like polymorphonuclear leukocytes [2], activated macrophages [3], and mast cells [4]. Dendritic cells (DC) are the major players in both innate and adaptive immunity [5]. Despite their important role as the most professional antigen-presenting cells (APC) of the immune system, DC possess the enzymatic machinery to convert AA to proinflammatory LTs $[6,7,8,9]$. Since, all human DC phenotypes examined until now constitutively express the 5-LO pathway, the role of DC 5-LOderived lipid mediators in the regulation of the proximal steps of the immune responses was recently suggested [8]. Primary immune response involves phenomena as diverse as antigen uptake by DC, their subsequent migration through multiple tissue barriers, homing in lymphoid organs, and antigen presentation to T cells $[8,9]$. LTs could play roles in each of these events. It is known that LTs exert their effects through extracellular G-protein-coupled receptors. Among human tissues studied by Northern blot analysis, $\mathrm{LTB}_{4}$ receptor messenger RNA (mRNA) is strongly expressed in both thymus [10] and lymph nodes (Spanbroek R. unpublished data), while CysLT1 receptor mRNA is expressed in spleen [11]. In addition, 5-LOdeficient mice show altered ovalbumin-dependent cellular and humoral immune responses $[12,13]$. These observations provided substantial support for an indispensable role of 5-LO pathway in the regulation of adaptive immunity. Since LTs display a great variety of biological effects, it is not surprising that cellular LT biosynthesis must be tightly regulated. Based in the current knowledge of 5-LO pathway regulation, it becomes obvious that cellular LT biosynthesis is modulated by multiple mechanisms, including gene expression, cytokine effects, enzyme movement, and compartmentalization of the 5-LO pathway. Thus the understanding of the precise regulatory mechanism of the 5-LO activity might provide new concepts for the development of anti-inflammatory drugs.

\section{5-LO PATHWAY AND LT BIOSYNTHESIS}

LTs are lipid messengers that play central role in immune responses and tissue homeostasis [14]. Biosynthesis of LTs from AA was initially described in polymorphonuclear leukocytes and monocytes. First described in 1937 as the slow reacting substances of anaphylaxis (SRS-A), these lipid mediators are now known as the cysteinyl LTs (CysLTs), LTC 4 , LTD 4 and LTE 4 [15]. Synthesis of LTs can be divided in two pathways: one to create CysLTs and another to create $\mathrm{LTB}_{4}$ (Figure 1). Some of important properties of 5-LO pathway proteins are summarized in Table 1. 5-LO is the key enzyme in LT biosynthesis and is located in the nucleus in some cell types and in the cytosol of others [16]. 5-LO is 72 - to $80-\mathrm{kd}$ monomeric soluble protein containing one nonheme iron believed necessary for catalysis [17]. 
Membrane phospholipids

Phospholipase $\mathrm{A}_{2}$

Arachidonic acid

FLAP

5-lipoxygenase

5-HPETE

[5-hydroperoxyeicosatertaenoic acid]

FLAP

5-lipoxygenase

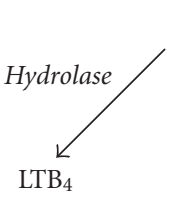

$\mathrm{LTA}_{4}$

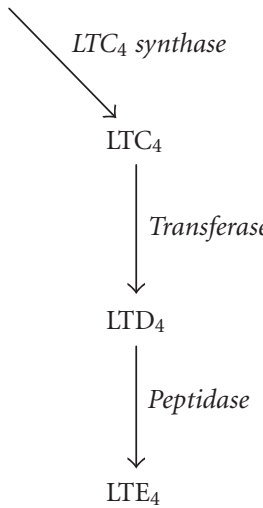

Figure 1. Pathways of LT biosynthesis. Arachidonic acid is liberated from membrane phospholipids by the action of cytosolic phospholipase $\mathrm{A}_{2}\left(\mathrm{cPLA}_{2}\right)$ and presented to 5-LO enzyme by FLAP. 5-LO enzyme converts arachidonic acid to an unstable intermediate termed 5-hydroperoxyeicosatetraenoic acid (5-HPETE). Subsequently, 5-HPETE is dehydrated to yield the epoxide $\mathrm{LTA}_{4}$, a pivotal intermediate in the biosynthesis of inflammatory and anaphylactic mediators. Enzymatic hydrolysis of $\mathrm{LTA}_{4}$ by $\mathrm{LTA}_{4}$ hydrolase results in the formation of $\mathrm{LTB}_{4}$. Alternatively, $\mathrm{LTC}_{4}$ synthase catalyzes the conjunction of $\mathrm{LTA}_{4}$ with glutathione to form $\mathrm{LTC}_{4}$, which may be converted to $\mathrm{LTD}_{4}$ and $\mathrm{LTE}_{4}$ by the actions of the transferase and peptidase enzymes, respectively.

This enzyme possesses an $\mathrm{NH}_{2}$-terminal domain that binds to calcium iron and is essential for nuclear membrane translocation [18]. Active mainly in myeloid cells, such as monocytes, macrophages, B lymphocytes, granulocytes, mast cells, and DC, 5-LO requires $\mathrm{Ca}^{2+}$ and is stimulated by ATP, phosphatidylcholine, lipids, and hydroperoxides [19]. Following cellular activation, 5-LO translocates to the nuclear membrane where it is able to interact with an 18-kd membrane-associated protein referred to as five-lipoxygenase-activating protein (FLAP). FLAP is an AA-binding protein whose function is to optimally present substrate to 5-LO [20]. The first evidence that the $18-\mathrm{kd}$ protein is absolutely required for cellular
5-LO activity comes from transfection studies in human osteosarcoma cell lines [21]. In this system, expression of 5-LO alone resulted in no detectable cellular 5-LO activity following challenge with calcium ionophore A-23187. LT synthesis only occurred when 5-LO and FLAP were coexpressed in these cells. FLAP is expressed on T cells [22], macrophages, and DC [6], but not on erythrocytes or endothelial cells.

Cellular activation by immune complexes, bacterial peptides, and other stimuli elicit a sequence of events that include cytosolic phospholipase $\mathrm{A}_{2}\left(\mathrm{cPLA}_{2}\right)$ and 5LO translocation to the nuclear envelope to produce 5hydroperoxy eicosatetraenoic acid (5-HPETE) from AA. Subsequently, 5-HPETE is dehydrated to yield the epoxide $\mathrm{LTA}_{4}$, a pivotal intermediate in the biosynthesis of inflammatory and anaphylactic mediators. LTA $_{4}$ undergoes transformation by one or more of three possible fates depending on the cellular context: hydrolysis, conjugation with glutathione, or transcellular metabolism to generate bioactive lipid mediators [23]. In neutrophils and monocytes, $\mathrm{LTA}_{4}$ is converted predominately to the chemoattractant $\mathrm{LTB}_{4}$ by $\mathrm{LTA}_{4}$ hydrolase [24], but in human eosinophils, mast cells, and basophils, $\mathrm{LTA}_{4}$ is conjugated with reduced glutathione by $\mathrm{LTC}_{4}$ synthase to form the first of the CysLTs, LTC 4 [25]. After carrier-mediated cellular export, sequential cleavage of the glutathionyl side chain of $\mathrm{LTC}_{4}$ generates the extracellular metabolites $\mathrm{LTD}_{4}$ and $\mathrm{LTE}_{4}$. $\mathrm{LTB}_{4}$ may be degraded by microsomal $\omega$ oxidation and peroxisomal $\beta$-oxidation in myeloid cells and hepatocytes. Degradation is accompanied by loss of biological activity. It is important to note that degradative enzymes are increased by the transcription factor peroxisome proliferator-activated receptor $\alpha(\operatorname{PPAR} \alpha)$ and this nuclear hormone receptor is in turn activated by binding with $\mathrm{LTB}_{4}$ [26]. This feedback loop limits the duration of action of $\mathrm{LTB}_{4}$.

\section{RECEPTORS FOR LEUKOTRIENES}

The actions of LTs require the expression of extracellular G-protein-coupled receptors (GPCR) which are members of the rhodopsin-like receptor superfamily. $\mathrm{LTB}_{4}$ is a potent chemoattractant that is primarily involved in inflammation, immune responses, and host defense against infection. $\mathrm{LTB}_{4}$ activates inflammatory cells by binding to its cell-surface receptor (designated BLT) via two known receptors, BLT1 and BLT2, according to the affinity of $\mathrm{LTB}_{4}$ for the receptor. BLT1 has been characterized as a 43-kd GPCR expressed only in inflammatory cells, including neutrophils, alveolar macrophages, and eosinophils and with a high affinity for only $\mathrm{LTB}_{4}$ [27]. The second G-protein-coupled receptor for $\mathrm{LTB}_{4}$, BLT2 receptor, has only recently been described and is a low-affinity receptor expressed more ubiquitously $[28,29]$. Both receptors are found in lymph node [30] on the same chromosome, but intriguingly, the promoter region of the BLT1 gene is localized within the open reading frame (ORF) of the BLT2 gene, which encodes a low-affinity 
TABLE 1. 5-lipoxygenase pathway proteins.

\begin{tabular}{|c|c|c|c|}
\hline 5-lipoxygenase & FLAP & $\mathrm{LTA}_{4}$ hydrolase & LTC $_{4}$ synthase \\
\hline $78 \mathrm{kd}$, cytosolic protein & $18 \mathrm{kd}$, membrane protein & $69 \mathrm{kd}$, cytosolic protein & $18 \mathrm{kd}$, membrane protein \\
\hline 673 amino acid & AA-binding protein & Converts $\mathrm{LTA}_{4}$ to $\mathrm{LTB}_{4}$ & Converts $\mathrm{LTA}_{4}$ to $\mathrm{LTC}_{4}$ \\
\hline Nonheme iron & Required for activation of 5-LO & & \\
\hline \multicolumn{4}{|l|}{$\begin{array}{l}\text { Translocated to cell membrane } \\
\text { after cell activation }\end{array}$} \\
\hline \multicolumn{4}{|l|}{$\begin{array}{l}\text { Dioxygenase activity converts AA } \\
\text { to 5-HPETE }\end{array}$} \\
\hline $\begin{array}{l}\text { Dehydratase activity converts } \\
5 \text {-HPETE to } \text { LTA }_{4}\end{array}$ & & & \\
\hline
\end{tabular}

receptor for $\mathrm{LTB}_{4}$ [27]. The high-affinity receptor BLT1 mediates chemotaxis, chemokinesis, aggregation, and adherence to endothelium. The low-affinity receptor BLT2 mediates degranulation and oxygen radical release [31]. Overexpression of $\mathrm{LTB}_{4}$ receptors in leukocytes leads to increased neutrophil influx into the lungs after ischemiareperfusion in mice [32]. It is also important to indicate that $\mathrm{LTB}_{4}$ can bind and activate the intranuclear transcription factor PPAR $\alpha$, resulting in the activation of genes that terminate inflammatory processes [10]. The receptor for cysteinyl LTs, $\mathrm{LTC}_{4}, \mathrm{LTD}_{4}$, and $\mathrm{LTE}_{4}$ are named CysLT receptors and are distinct from the $\mathrm{LTB}_{4}$ receptors. Two classes of CysLT receptors have been identified: CysLT1 and CysLT2 according to their sensitivity to selective LT receptor antagonists. CysLT1 has been identified in human smooth muscle cells [11], vascular endothelial cells [33], lung macrophages, and peripheral blood leukocytes. CysLT2 receptor, originally found in pulmonary vein preparations [34] by pharmacological assays, is detected in spleen, Purkinje fibers of the heart, and discreet region of the adrenal gland by molecular methods.

\section{REGULATORY MECHANISMS OF CELLULAR LT BIOSYNTHESIS}

Abnormal production of LT contributes to a variety of inflammatory diseases, including asthma, glomerulonephritis, psoriasis, inflammatory bowel diseases, and acute lung injury [35]. Considering their important role in host defense against microbial infections [36], biosynthesis of LTs must be tightly regulated. Two steps seem to be involved in the control of LT biosynthesis, that is, liberation of AA and regulation of 5-LO activity [37]. Moreover, the expression of 5-LO and FLAP, which are subject to regulation in monocytic cells [38], have been considered as the major determinant of cellular LT biosynthesis [39]. 5-LO activity and product generation at sites of inflammation might be modulated in multiple ways. The most obvious would be the recruitment and stimulation of additional inflammatory cells. Another possibility is modulating the expression of enzymatic components through transcriptional or posttranscriptional mechanisms. Recently, it has been reported that cyclic AMP (cAMP) elevating agents, such as $\mathrm{PGE}_{2}$, inhibited LT biosynthesis and 5-LO translocation to the nucleus in cytokine-primed human neutrophils [40]. The intracellular compartmentalization of the 5-LO metabolism affects the integrated output of this biosynthetic pathway [41]. Nuclear import of 5-LO can modulate LT production, since nuclear import can strongly enhance [42] or suppress [43] 5-LO activity. In considering the question of 5-LO translocation and its cellular localization, it is necessary to consider that 5-LO can move in or out of the nucleus in response to in vivo or in vitro experimental conditions [41]. Cytokines and other components may also affect 5-LO pathway, and the expression of 5-LO and FLAP can be controlled by specific molecules. For example, it has been reported that the Th2-derived cytokines, IL-4, and IL-13 inhibited the release of LT from monocytes by decreasing FLAP mRNA and protein levels, whereas, IL-1 and IFN $\gamma$ (Th1 cytokines) stimulate 5-LO expression [39]. 5-LO activity may be modulated by nitric oxide (NO) since prolonged exposure to lipopolysaccharide inhibits macrophage 5-LO metabolism via induction of NO synthesis [44]. In bone marrow-derived DC, we have recently demonstrated that exogenous or $\mathrm{PGE}_{2}$-induced IL-10 inhibited FLAP expression without any effect on 5LO enzyme [6]. The regulatory mechanisms of the 5-LO pathway appear to be complex and depends on the composition of the investigated cell populations. Specific control of 5-LO pathway has long been suspected because expression of 5-LO activity is tissue specific and narrowly distributed to inflammatory cells. It is also important to note that there is wide variation in 5-LO activity and in 5LO and FLAP levels even among different inflammatory cell types.

\section{5-LO PATHWAY AND CELLS OF IMMUNE SYSTEM: WHAT ABOUT DENDRITIC CELLS?}

One of the best known and most well-studied LTs is $\mathrm{LTB}_{4}$. $\mathrm{LTB}_{4}$ is produced by many cells of the immune 


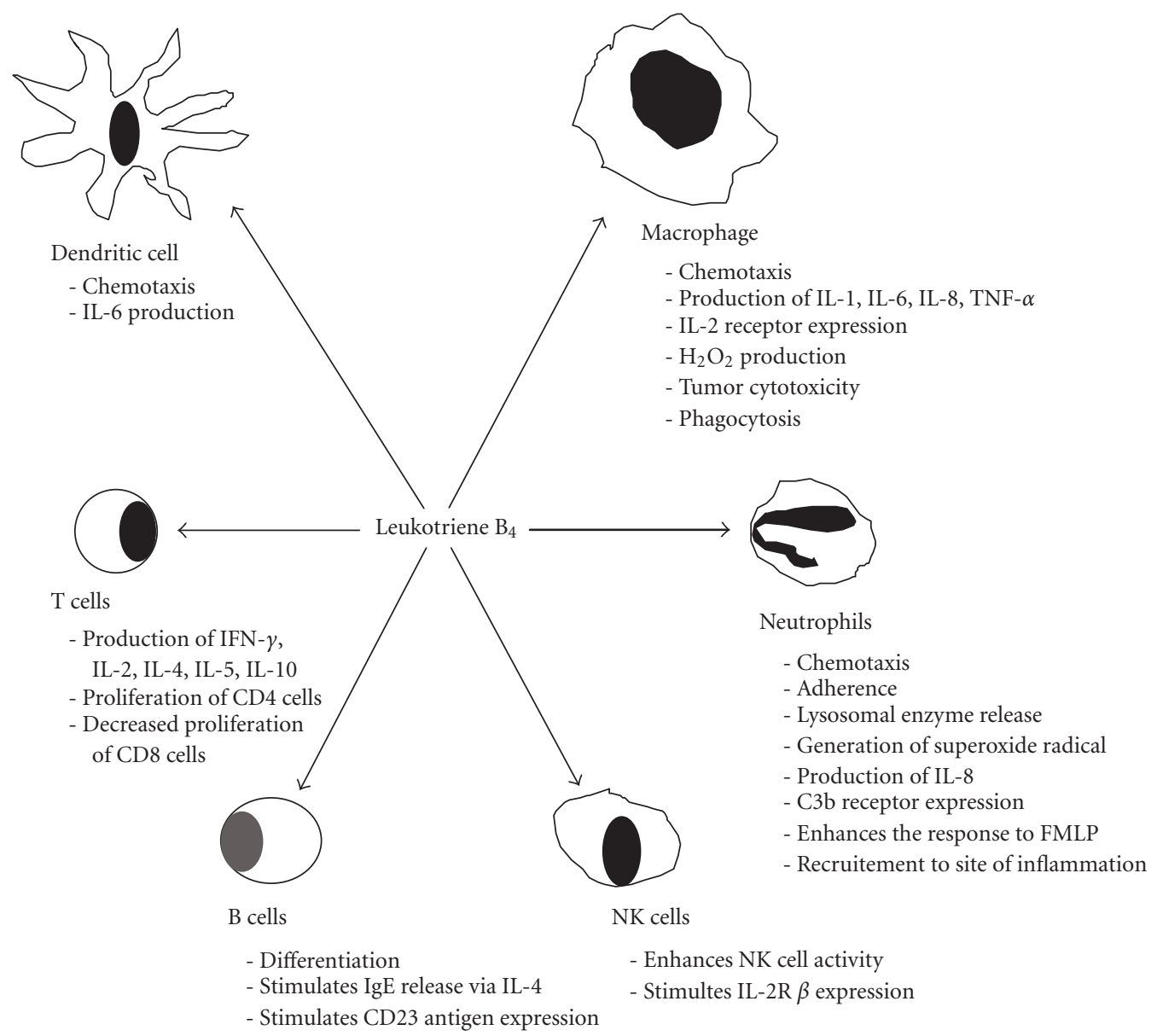

FIgURE 2. Effects of $\mathrm{LTB}_{4}$ on cells of immune system.

system, including activated neutrophils stimulated with AA or calcium ionophore [45], macrophages, DC, and T cells $[46,47]$. This lipid mediators has diverse effects on the function and activities of cells of the immune system (Figure 2). Several observations have suggested that $\mathrm{LTB}_{4}$, in cooperation with monocytes, stimulates T-suppressorcell functions $[48,49]$. These effects appeared to be exerted through inhibition of $\mathrm{T} \mathrm{CD}^{+}$(helper/inducer) subsets and enhancement of $\mathrm{T} \mathrm{CD}^{+}$(suppressor/cytotoxic) subsets [50]. The suppression required the presence of monocytes and was induced by the cyclooxygenase inhibitors [51]. It has been suggested that the mechanism of action involved induction of monocytes to produce both prostaglandins (metabolites of cyclooxygenase pathways) and cytokines, such as IFN- $\gamma$, IL-2, which in turn lead to the production of IL-1 $[52,53]$. Thus, the effects of $\mathrm{LTB}_{4}$ on $\mathrm{T}$ lymphocytes are not the result of a direct action on lymphocytes themselves but an indirect action via monocytes. On natural killer (NK) cells, $\mathrm{LTB}_{4}$ significantly augmented NK cell cytotoxicity and stimulated the expression of IL- $2 \beta$ receptors when added to effector target cocultures $[54,55] . \mathrm{LTB}_{4}$ is also known to enhance B cell differentiation and secretion of IgE via an IL-4-dependent mechanism [56]. $\mathrm{LTB}_{4}$ causes adhesion and chemotactic movement of leukocytes and stimulates aggregation, enzyme release, and generation of superoxide in neutrophils. Leukotrienes $\mathrm{C}_{4}, \mathrm{D}_{4}$, and $\mathrm{E}_{4}$, which are released from the lung tissue of asthmatic subjects exposed to specific allergens, seem to play a pathophysiological role in immediate hypersensitivity reactions. The expression of 5-LO and FLAP genes have been reported in human B cells by reversed transcription chain analysis [22]. Several AAderived lipid mediators possess immunoregulatory properties in vivo and in vitro. The most interesting example is $\mathrm{PGE}_{2}$, which clearly affects the functions of DC and other cell types of the immune system [57]. In contrast to $\mathrm{PGE}_{2}, \mathrm{LTB}_{4}$ is considered as a mainly immunopotentiating mediator, which stimulates the activity of NK cells and B lymphocytes, although it also induces suppressor function among human mononuclear leukocytes. LTB $_{4}$ can augment proliferation of mixed $\mathrm{T}$ lymphocytes and of $\mathrm{OKT}^{+}$cells [58]. It also stimulates the release of IL- 1 and TNF- $\alpha$ in human monocytes [59], and IL- 8 from human polymorphonuclear leukocytes [60]. 
Cells that produce LTs or become targets to their actions can also produce other proinflammatory molecules, such as PGs, and various cytokines. For example, the exogenously added or the endogenously produced $\mathrm{LTB}_{4}$ can enhance the release of IL-6 from human monocytes [61] and mice DC [6]. This may constitute an important mean by which monocytes and DC modulate inflammatory responses. Several lines of evidence support an expanded role of the 5-LO pathway in the regulation of antigenspecific adaptive immunity. Epidermal Langerhans cells (LC), a member of the DC family capable of initiating antigen-specific immune responses in naive lymphocytes, markedly express the 5-LO pathway [9]. We have recently demonstrated that mice bone marrow-derived DC (BMDC) produce $\mathrm{LTB}_{4}$ and other AA metabolites, which have an autocrine actions in APC-mediated immunity [6, 7]. Other investigators have reported the expression of 5LO in human DC generated from CD $34^{+}$hematopoietic progenitors and in lymphoid organs [8]. It has been recently reported that BM-DC express CysLT1 receptors, 5LO, FLAP, and $\mathrm{LTC}_{4}$ synthase, and produce CysLTs in response to aeroallergen [62]. The produced CysLTs play a crucial role in regulating DC function in a murine model for asthma. The ability of DC to migrate to lymphoid nodes may be affected by 5 -LO products since the $\mathrm{LTC}_{4}$ transporter MRP1 may regulate CCL19-dependent mobilization of DC from peripheral tissues to lymph nodes [63]. Taken together, these data suggest that by producing proinflammatory LTs and other components, DC and other APC may play important role in inflammatory processes and allergic diseases.

\section{CONCLUDING REMARKS}

The main function of the immune system is the defence of the host against pathogens and tumors. Two major defence systems are involved in host defence against infectious agents and tumors: the innate and adaptive immunity, which differ in the means by which they recognize antigens. However, it is important to indicate that innate immune system activates, orientates, and regulates the adaptive immunity, which through clonal expansion of lymphocytes will respond to pathogen in antigen specific manner. Both innate and adaptive immunity are closely linked, and the interactions between the two systems of the host defence are regulated by a variety of cells and their mediators in particular cytokines and AA-derived lipid mediators, such as LTs.

The development of specific agonists and antagonists for each LT receptors will provide important reagent for further defining the biological and pathological actions of proinflammatory LTs. Other lipoxygenase products will also certainly receive attention in the year to come. To delineate molecular mechanisms within immune responses that are affected by 5-LO pathway products, future studies should be directed toward DC/T lymphocytes interactions, the identification of LT receptor-expressing cells in lymphoid organs, and immune response studies of 5LO knockout mice. Finally, further studies of LT receptors expression in different types of DC and other APC are needed to truly assess the potential roles of 5-LO pathway in DC biology and APC-mediated immunity.

\section{ACKNOWLEDGMENT}

This work is supported by La Ligue Régionale Contre le Cancer, Comité Départemental des Charentes et de la Gironde.

\section{REFERENCES}

[1] Samuelsson B. Leukotrienes: mediators of immediate hypersensitivity reactions and inflammation. Science. 1983;220(4597):568-575.

[2] Brock TG, McNish RW, Coffey MJ, Ojo TC, Phare SM, Peters-Golden M. Effects of granulocyte-macrophage colony-stimulating factor on eicosanoid production by mononuclear phagocytes. J Immunol. 1996;156(7):2522-2527.

[3] Chensue SW, Kunkel SL. Arachidonic acid metabolism and macrophage activation. Clin Lab Med. 1983;3(4):677-694.

[4] Ramos BF, Zhang Y, Qureshi R, Jakschik BA. Mast cells are critical for the production of leukotrienes responsible for neutrophil recruitment in immune complex-induced peritonitis in mice. J Immunol. 1991;147(5):1636-1641.

[5] Banchereau J, Steinman RM. Dendritic cells and the control of immunity. Nature. 1998;392(6673):245252.

[6] Harizi H, Juzan M, Moreau JF, Gualde N. Prostaglandins inhibit 5-lipoxygenase-activating protein expression and leukotriene $\mathrm{B}_{4}$ production from dendritic cells via an IL-10-dependent mechanism. J Immunol. 2003;170(1):139-146.

[7] Harizi H, Gualde N. Dendritic cells produce eicosanoids, which modulate generation and functions of antigen-presenting cells. Prostaglandins Leukot Essent Fatty Acids. 2002;66(5-6):459-466.

[8] Spanbroek R, Hildner M, Steinhilber D, et al. 5lipoxygenase expression in dendritic cells generated from CD $34^{+}$hematopoietic progenitors and in lymphoid organs. Blood. 2000;96(12):3857-3865.

[9] Spanbroek R, Stark HJ, Janssen-Timmen U, et al. 5-Lipoxygenase expression in Langerhans cells of normal human epidermis. Proc Natl Acad Sci USA. 1998;95(2):663-668.

[10] Yokomizo T, Izumi T, Chang K, Takuwa Y, Shimizu T. A G-protein-coupled receptor for leukotriene B4 that mediates chemotaxis. Nature. 1997;387(6633):620-624.

[11] Lynch KR, O’Neill GP, Liu Q, et al. Characterization of the human cysteinyl leukotriene CysLT1 receptor. Nature. 1999;399(6738):789-793. 
[12] Wills-Karp M. Immunologic basis of antigeninduced airway hyperresponsiveness. Annu Rev Immunol. 1999;17:255-281.

[13] Funk CD. The molecular biology of mammalian lipoxygenases and the quest for eicosanoid functions using lipoxygenase-deficient mice. Biochim Biophys Acta. 1996;1304(1):65-84.

[14] Funk CD. Prostaglandins and leukotrienes: advances in eicosanoid biology. Science. 2001;294(5548): 1871-1875.

[15] Lewis RA, Austen KF, Soberman RJ. Leukotrienes and other products of the 5-lipoxygenase pathway. Biochemistry and relation to pathobiology in human diseases. N Engl J Med. 1990;323(10):645-655.

[16] Peters-Golden M, Brock TG. Intracellular compartmentalization of leukotriene synthesis: unexpected nuclear secrets. FEBS Lett. 2001;487(3):323-326.

[17] Rouzer CA, Shimizu T, Samuelsson B. On the nature of the 5-lipoxygenase reaction in human leukocytes: characterization of a membraneassociated stimulatory factor. Proc Natl Acad Sci USA. 1985;82(22):7505-7509.

[18] Chen XS, Funk CD. The N-terminal "betabarrel" domain of 5-lipoxygenase is essential for nuclear membrane translocation. J Biol Chem. 2001;276(1):811-818.

[19] Radmark O. Arachidonate 5-lipoxygenase. Prostaglandins Other Lipid Mediat. 2002;68-69:211234.

[20] Mancini JA, Abramovitz M, Cox ME, et al. 5lipoxygenase-activating protein is an arachidonate binding protein. FEBS Lett. 1993;318(3):277-281.

[21] Dixon RA, Diehl RE, Opas E, et al. Requirement of a 5-lipoxygenase-activating protein for leukotriene synthesis. Nature. 1990;343(6255):282-284.

[22] Jakobsson PJ, Steinhilber D, Odlander B, Radmark O, Claesson HE, Samuelsson B. On the expression and regulation of 5-lipoxygenase in human lymphocytes. Proc Natl Acad Sci USA. 1992;89(8):35213525.

[23] Gronert K, Clish CB, Romano M, Serhan CN. Transcellular regulation of eicosanoid biosynthesis. Methods Mol Biol. 1999;120:119-144.

[24] Radmark O, Shimizu T, Jornvall H, Samuelsson B. Leukotriene A4 hydrolase in human leukocytes. Purification and properties. J Biol Chem. 1984;259(20):12339-12345.

[25] Yoshimoto T, Soberman RJ, Spur B, Austen KF. Properties of highly purified leukotriene C4 synthase of guinea pig lung. J Clin Invest. 1988;81(3):866-871.

[26] Devchand PR, Keller H, Peters JM, Vazquez M, Gonzalez FJ, Wahli W. The PPARalpha-leukotriene $\mathrm{B}_{4}$ pathway to inflammation control. Nature. 1996;384(6604):39-43.

[27] Kato K, Yokomizo T, Izumi T, Shimizu T. Cell-specific transcriptional regulation of human leukotriene $\mathrm{B}_{4}$ receptor gene. J Exp Med. 2000;192(3):413-420.
[28] Yokomizo T, Kato K, Hagiya H, Izumi T, Shimizu T. Hydroxyeicosanoids bind to and activate the low affinity leukotriene $\mathrm{B}_{4}$ receptor, BLT2. J Biol Chem. 2001;276(15):12454-12459.

[29] Kamohara M, Takasaki J, Matsumoto M, et al. Molecular cloning and characterization of another leukotriene $\mathrm{B}_{4}$ receptor. $\mathrm{J}$ Biol Chem. 2000;275(35):27000-27004.

[30] Christie PE, Henderson WR Jr. Lipid inflammatory mediators: leukotrienes, prostaglandins, platelet-activating factor. Clin Allergy Immunol. 2002;16:233-254.

[31] Henderson WR Jr. The role of leukotrienes in inflammation. Ann Intern Med. 1994;121(9):684-697.

[32] Chiang N, Gronert K, Clish CB, O’Brien JA, Freeman $\mathrm{MW}$, Serhan $\mathrm{CN}$. Leukotriene $\mathrm{B}_{4}$ receptor transgenic mice reveal novel protective roles for lipoxins and aspirin-triggered lipoxins in reperfusion. J Clin Invest. $1999 ; 104(3): 309-316$

[33] Gronert K, Martinsson-Niskanen T, Ravasi S, Chiang N, Serhan CN. Selectivity of recombinant human leukotriene $\mathrm{D}_{4}$, leukotriene $\mathrm{B}_{4}$, and lipoxin $\mathrm{A}_{4}$ receptors with aspirin-triggered 15-epi-LXA 4 and regulation of vascular and inflammatory responses. Am J Pathol. 2001;158(1):3-9.

[34] Nicosia S, Capra V, Accomazzo AR, et al. Receptors and second messengers for Cys-leukotrienes. In: Folco GC, Samuelsson B, Maclouf JA, Velo GP, Eds. Eicosanoids: From Biotechnology to Therapeutic Applications. New York:Plenum Press; 1996: 127-136.

[35] Goetzl EJ, An S, Smith WL. Specificity of expression and effects of eicosanoid mediators in normal physiology and human diseases. FASEB $J$. 1995;9(11):1051-1058.

[36] Bailie MB, Standiford TJ, Laichalk LL, Coffey MJ, Strieter R, Peters-Golden M. Leukotriene-deficient mice manifest enhanced lethality from Klebsiella pneumonia in association with decreased alveolar macrophage phagocytic and bactericidal activities. $J$ Immunol. 1996;157(12):5221-5224.

[37] Steinhilber D. 5-Lipoxygenase: enzyme expression and regulation of activity. Pharm Acta Helv. 1994;69(1):3-14.

[38] Bennett CF, Chiang MY, Monia BP, Crooke ST. Regulation of 5-lipoxygenase and 5-lipoxygenaseactivating protein. expression in HL-60 cells. Biochem J. 1993;289(pt 1):33-39.

[39] Nassar GM, Montero A, Fukunaga M, Badr KF. Contrasting effects of proinflammatory and Thelper lymphocyte subset-2 cytokines on the 5lipoxygenase pathway in monocytes. Kidney Int. 1997;51(5):1520-1528.

[40] Flamand N, Surette ME, Picard S, Bourgoin S, Borgeat P. Cyclic AMP-mediated inhibition of 5lipoxygenase translocation and leukotriene biosynthesis in human neutrophils. Mol Pharmacol. 2002;62(2):250-256. 
[41] Peters-Golden M, Brock TG. Intracellular compartmentalization of leukotriene biosynthesis. Am J Respir Crit Care Med. 2000;161 (pt 2):36-40.

[42] Hsieh FH, Lam BK, Penrose JF, Austen KF, Boyce JA. $\mathrm{T}$ helper cell type 2 cytokines coordinately regulate immunoglobulin E-dependent cysteinyl leukotriene production by human cord blood-derived mast cells: profound induction of leukotriene $\mathrm{C}_{4}$ synthase expression by interleukin 4. J Exp Med. 2001;193(1):123-133.

[43] Brock TG, Anderson JA, Fries FP, Peters-Golden M, Sporn PH. Decreased leukotriene $\mathrm{C}_{4}$ synthesis accompanies adherence-dependent nuclear import of 5-lipoxygenase in human blood eosinophils. J Immunol. 1999;162(3):1669-1676.

[44] Coffey MJ, Phare SM, Peters-Golden M. Prolonged exposure to lipopolysaccharide inhibits macrophage 5-lipoxygenase metabolism via induction of nitric oxide synthesis. J Immunol. 2000;165(7):3592-3598.

[45] Ford-Hutchinson, AW, Bray, MA, Doig, MV, Shipley, ME, Smith, MJ. Leukotriene B, a potent chemokinetic and aggregating substance released from polymorphonuclear leukocytes. Nature. 1980;286:264265.

[46] Goetzl EJ. Selective feed-back inhibition of the 5-lipoxygenation of arachidonic acid in human T-lymphocytes. Biochem Biophys Res Commun. 1981;101(2):344-350.

[47] Goodwin JS, Atluru D, Sierakowski S, Lianos EA. Mechanism of action of glucocorticosteroids. Inhibition of $\mathrm{T}$ cell proliferation and interleukin 2 production by hydrocortisone is reversed by leukotriene $\mathrm{B}_{4}$. J Clin Invest. 1986;77(4):1244-1250.

[48] Rola-Pleszczynski M, Borgeat P, Sirois P. Leukotriene $\mathrm{B}_{4}$ induces human suppressor lymphocytes. Biochem Biophys Res Commun. 1982;108(4):1531-1537.

[49] Payan DG, Goetzl EJ. Specific suppression of human T lymphocyte function by leukotriene $\mathrm{B}_{4}$. J Immunol. 1983;131(2):551-553.

[50] Payan DG, Missirian-Bastian A, Goetzl EJ. Human T-lymphocyte subset specificity of the regulatory effects of leukotriene $\mathrm{B}_{4}$. Proc Natl Acad Sci USA. 1984;81(11):3501-3505.

[51] Rola-Pleszczynski M. Differential effects of leukotriene $\mathrm{B}_{4}$ on $\mathrm{T}^{+}$and $\mathrm{T}^{+}$lymphocyte phenotype and immunoregulatory functions. J Immunol. 1985;135(2):1357-1360.

[52] Rola-Pleszczynski M, Lemaire I. Leukotrienes augment interleukin 1 production by human monocytes. J Immunol. 1985;135(6):3958-3961.

[53] Rola-Pleszczynski M, Chavaillaz PA, Lemaire I. Stimulation of interleukin 2 and interferon gamma production by leukotriene $\mathrm{B}_{4}$ in human lymphocyte cultures. Prostaglandins Leukot Med. 1986;23(23):207-210.

[54] Gagnon L, Girard M, Sullivan AK, Rola-Pleszczynski M. Augmentation of human natural cytotoxic cell activity by leukotriene $\mathrm{B}_{4}$ mediated by enhanced effector-target cell binding and increased lytic efficiency. Cell Immunol. 1987;110(2):243-252.

[55] Rola-Pleszczynski M, Gagnon L, Sirois P. Leukotriene $\mathrm{B}_{4}$ augments human natural cytotoxic cell activity. Biochem Biophys Res Commun. 1983;113(2):531-537.

[56] Crooks SW, Stockley RA. Leukotriene $\mathrm{B}_{4}$. Int J Biochem Cell Biol. 1998;30(2):173-178.

[57] Harizi H, Grosset C, Gualde N. Prostaglandin $E_{2}$ modulates dendritic cell function via $\mathrm{EP}_{2}$ and $\mathrm{EP}_{4}$ receptor subtypes. J Leukoc Biol. 2003;73(6):756763.

[58] Gualde N, Atluru D, Goodwin JS. Effect of lipoxygenase metabolites of arachidonic acid on proliferation of human T cells and T cell subsets. J Immunol. 1985;134(2):1125-1129.

[59] Dubois CM, Bissonnette E, Rola-Pleszczynski M. Asbestos fibers and silica particles stimulate rat alveolar macrophages to release tumor necrosis factor. Autoregulatory role of leukotriene $\mathrm{B}_{4}$. Am Rev Respir Dis. 1989;139(5):1257-1264.

[60] McCain RW, Holden EP, Blackwell TR, Christman JW. Leukotriene $\mathrm{B}_{4}$ stimulates human polymorphonuclear leukocytes to synthesize and release interleukin-8 in vitro. Am J Respir Cell Mol Biol. 1994;10(6):651-657.

[61] Rola-Pleszczynski M, Stankova J. Leukotriene $B_{4}$ enhances interleukin-6 (IL-6) production and IL6 messenger RNA accumulation in human monocytes in vitro: transcriptional and posttranscriptional mechanisms. Blood. 1992;80(4):1004-1011.

[62] Machida I, Matsuse H, Kondo Y, et al. Cysteinyl leukotrienes regulate dendritic cell functions in a murine model of asthma. J Immunol. 2004;172(3):1833-1838.

[63] Robbiani DF, Finch RA, Jager D, Muller WA, Sartorelli AC, Randolph GJ. The Leukotriene $C_{4}$ transporter MRP1 regulates CCL19 (MIP-3beta, ELC)dependent mobilization of dendritic cells to lymph nodes. Cell. 2000;103(5):757-768.

* Corresponding author.

E-mail: harizihedi33@yahoo.fr

Fax: + 335575714 72; Tel: + 33557571701 

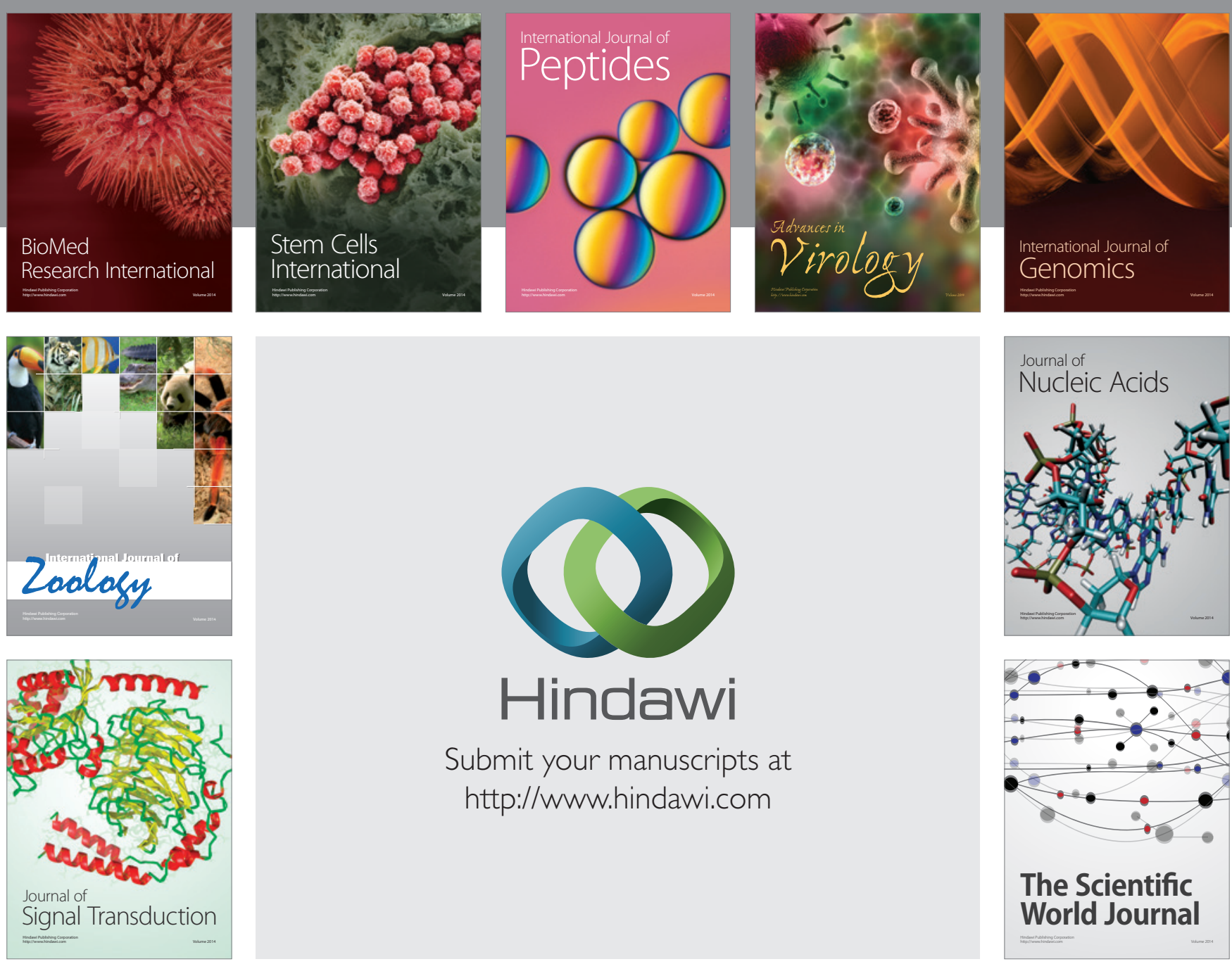

Submit your manuscripts at

http://www.hindawi.com
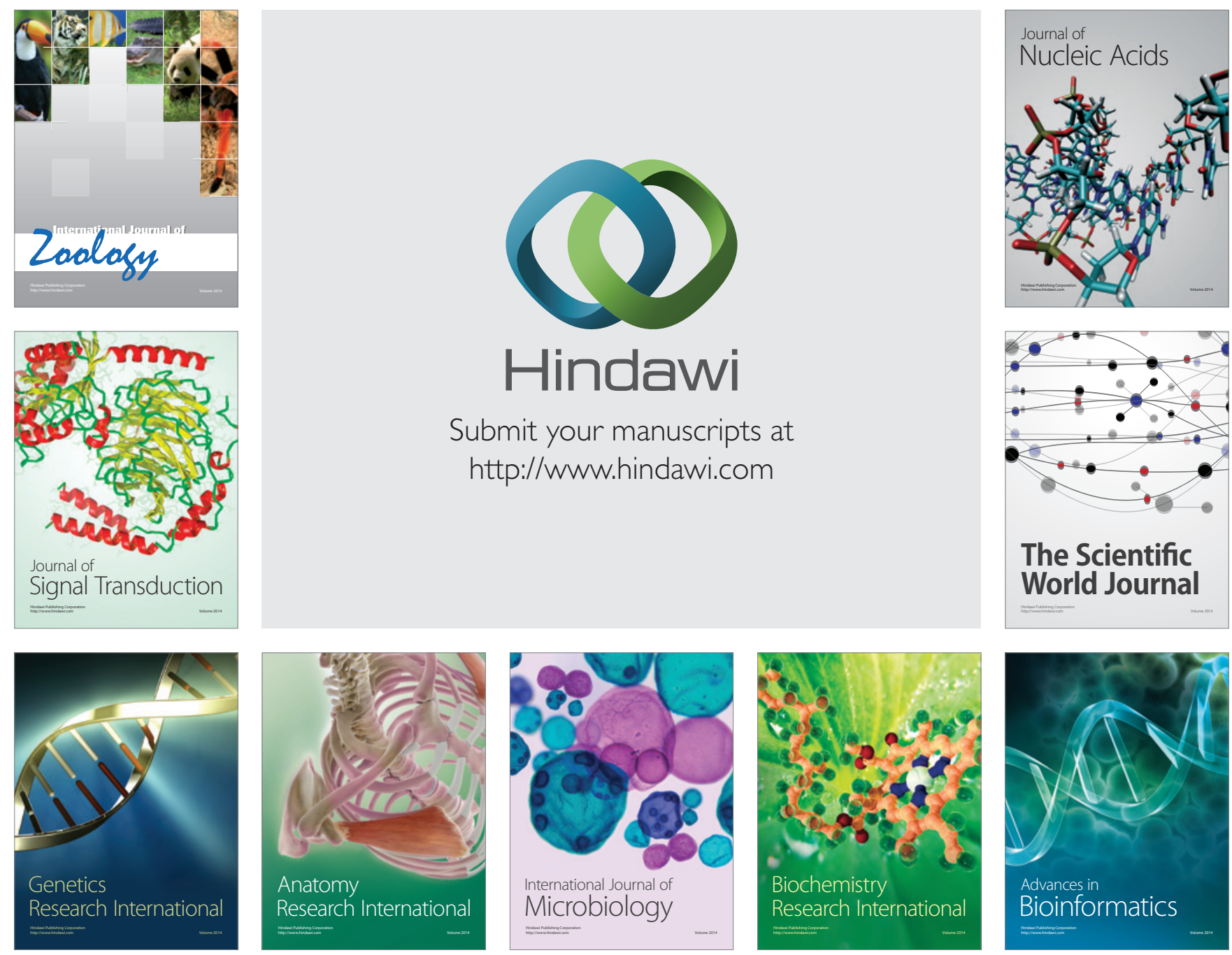

The Scientific World Journal
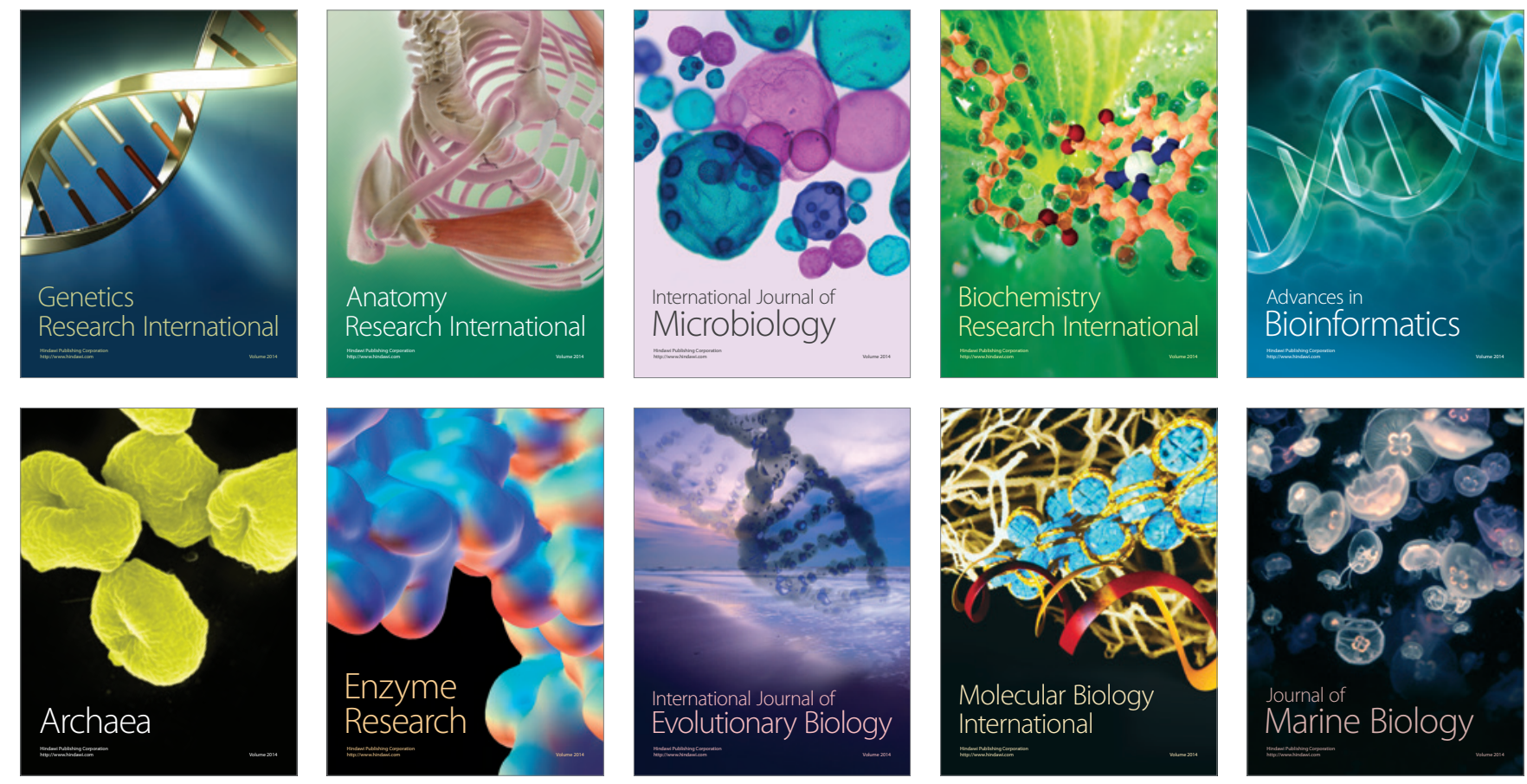